\title{
Pharmacologist's View of the New Corona Virus
}

\section{To the Editor}

Despite many advances in the prevention and treatment of infectious diseases, the global spread of infections is accelerated by close contact among concentrated populations. A pandemic caused by a new type of coronavirus (SARS-CoV-2) continues to spread across the globe. This new disease attributed to COVID-19 emerged a century after the Spanish flu pandemic, which affected one-third of the world's population, killing more than 50 million people. ${ }^{1}$ The disease, caused by the $\mathrm{H} 1 \mathrm{~N} 1$ virus, has been around for less than two years and it is still unclear what contributed to its termination; possibly a mutation of the virus reduced its viral strength. Since information about biological sciences and human medicine is far more advanced today than at the beginning of the 2oth century, it is expected that the current pandemic will be contained, regardless of the potential for viral mutation. Scientists and doctors now face an urgent task - how to treat numerous sick people and stop the spread of this infection. The pandemic urgently requires identification of preventive measures, along with optimum means of diagnosis and treatment and data on dissemination of the infection, duration of incubation, clinical features of the disease, along with the best means of diagnosis and treatment for a very large number of people, and ultimately the long lasting consequences of the disease. In addition, we must identify pathways for the spread of the virus, its persistence on various surfaces and means of its inactivation. ${ }^{2}$

\section{Epidemiology and basic sciences}

Since no cure exists, as yet, for this viral disease, and it will take time to produce a suitable vaccine, strict epidemiological measures were implemented initially. This resulted in the largest quarantine in history - between 50 and 60 million people in several Chinese cities were isolated, group meetings were cancelled, schools were closed, and travel was prohibited. Later evaluation will show whether all of these epidemiological measures were justified. When analyses of deaths due to infection were made, the lowest mortality due to COVID-19 infection was found in patients with lung disease, compared to individuals who suffer from the heart diseases or diabetes. The mortality of hypertensive individuals due to the new coronavirus is similar to that of patients with lung disease.

Researchers almost immediately, in January 2020, identified the genome of the new virus, which made it possible to compare this new SARS-CoV-2 with an older coronavirus, SARS-CoV. The SARS-CoV, which originated in bats, caused a viral epidemic in 2002-2003. The genetic similarity of old and new corona viruses has been shown to be greater than $70 \% .^{3}$ Thus, the new corona virus is a combination of the bat virus with an unknown virus source. The snake virus seems to be the reservoir of that combined virus. Earlier, it was found that the older coronavirus (SARS-CoV) binds to the receptor for the angiotensin converting enzyme-2 (ACE-2), which is found at the airway cells localised in the alveoli.

\section{Usage of the approved medications}

Doctors quickly looked to see if any existing medicines could affect the COVID-19; the fastest way for treatment would be to use approved medicines proven to help resist invading pathogens. Development of specific drugs to treat this new illness may take several years and will require clinical trials; this will require time that we do not have. Enlistment of existing, safe medications, such as atorvastatin, met-

Copyright $\odot 2020$ Igić. This is an open access article distributed under the Creative Commons Attribution License (CC BY), which permits unrestricted use, distribution, and reproduction in any medium, provided the original work is properly cited.

This article should be cited as follows: Igić R. Pharmacologist's view of the new corona virus. Scr Med 2020;51(1):6-8. 
formin, glitazones, cyclosporine, interferon beta-1, ribavirin, antiviral peptides, nutrient supplements (especially zinc, which has anti-viral activity) should help patients resist the invading virus. ${ }^{4}$ In addition, biologics that reduce immunopathology and stimulate immune responses can be employed.

The Chinese reported efficacy of chloroquine, an antimalarial drug for treatment of the infection. ${ }^{5}$ Then, French researchers found, in a small group of patients with COVID-19 infection, that combined administration of hydroxychloroquine and azithromycin had produced even better results. ${ }^{6}$ Although that study was insufficient, it indicated a path to treatment, regardless of some serious side effects of azithromycin (severe diarrhoea due to Clostridium difficile and prolonged Q-T interval on the ECG). Despite these drawbacks, mortality due to infection with the new virus could be significantly reduced.

Some pharmacologists believe that because certain growth-inhibiting agents, such as cepharanthin, selamectin or mefloquine hydrochloride, affect replication of coronaviruses in vitro, these agents might be used to treat COVID-19 infection in vivo, but it will first be necessary to check their clinical efficacy. Cepharanthin (an ingredient in the local plant Stephania cephalantha) has been used in Japan since almost 70 years ago for a number of acute and chronic diseases because it has various pharmacological effects, including anti-inflammatory, anticancer, and antiviral effects. ${ }^{7}$

There is a considerable debate among biomedical scientists and physicians as to whether patients should stop taking ACE inhibitors (ACEI: enalapril, lisinopril, ramipril and others) and angiotensin receptor blocking drugs (ARB: losartan, eprosartan, valsartan and others) due to their increase of ACE-2 activity and rise of the ACE-2 receptors. ${ }^{8}$ These drugs help thousands of patients with high blood pressure, chronic heart failure, diabetic kidney damage and other vascular disorders. ${ }^{9}$ Discontinuing these medicines could have many serious consequences, although medical opinions remain divided.${ }^{10}$ On the one hand, there is an indication that these renin-angiotensin blockers could exacerbate coronavirus disease, but on the other hand, some preliminary data show that they are beneficial. ${ }^{11}$ Controlled clinical trials will establish whether these drugs should be temporarily discontinued (and in which patients) or whether they should even be given to individuals infected with COVID-19. For now, no one should omit taking any of these medicines.

\section{Epilogue}

It is worth noting that since the year 1940 until now, around 400 new infectious pathogens have been identified, ${ }^{12}$ providing an opportunity for scientific researchers to better treat and eliminate new infections. The production of vaccines and vaccination of a significant part of the population has proven successful in previous dangerous infections, but it is a time-consuming procedure. It remains imperative for us to quickly identify drugs that will, in the meantime, reduce mortality and prevent the spread of infection.

\section{Professor Rajko Igić}

Stroger Hospital of Cook County, Chicago, IL 60612, USA

Department of Pharmacology, Toxicology and Clinical Pharmacology,

Faculty of Medicine, University of Banjaluka, Banja Luka,

The Republic of Srpska, Bosnia and Herzegovina 


\section{References}

1. Taubenberger JK, Kash JC, Morens DM. The 1918 influenza pandemic: 100 years of questions answered and unanswered. Sci Transl Med 2019;11(502). doi: 10.1126/scitranslmed.aau5485.

2. Kampf G, Todt D, Pfaender S, Steinmann E. Persistence of coronaviruses on inanimate surfaces and their inactivation with biocidal agents. J Hosp Infect 2020;104(3):246-51.

3. Hui DS, Azhar EI, Madani TA, Ntoumi F, Kock R, Dar $\mathrm{O}$, et al. The continuing 2019-nCoV epidemic threat of novel coronaviruses to global health - the latest 2019 novel coronavirus outbreak in Wuhan, China. Int J Infect Dis 2020;91:264-6.

4. Zumla A, Hui DS, Azhar EI, Memish ZA, Maeurer M. Reducing mortality from 2019-nCoV: host-directed therapies should be an option. Lancet 2020 Feb 22;395(10224):e35-e36. doi: 10.1016/So1406736(20)30305-6.

5. Gao J, Yang ZTX. Breakthrough: Chloroquine phosphate has shown apparent efficacy in treatment of COVID-19 associated pneumonia in clinical studies. BioSci Trends 2020;14(1):72-3.

6. Gautret P, Lagier J-C, Parola P, Hoang VT, Meddeb L, Mailhe M, et al. Hydroxychloroquine and azithromycin as a treatment of COVID-19: results of an openlabel non-randomized clinical trial. Int J Antimicrob Agents 2020 Mar 20:105949. doi: 10.1016/j.ijantimicag.2020.105949.
7. Bailly C. Cepharanthine: An update of its mode of action, pharmacological properties and medical applications. Phytomedicine 2019 Sep;62:152956. doi: 10.1016/j.phymed.2019.152956.

8. Hoffmann M, Kleine-Weber H, Schroeder S, Krüger $\mathrm{N}$, Herrler T, Erichsen S, et al. SARS-CoV-2 cell entry depends on ACE2 and TMPRSS2 and is blocked by a clinically proven protease inhibitor. Cell 2020 Mar 4. pii: Soo92-8674(20)30229-4. doi: 10.1016/j. cell.2020.02.052.

9. Igić R. [Pharmacology of the renin-angiotensin system]. Banja Luka: Faculty of Medicine, University of Banja Luka; 2014.

10. Thomson GA. Where are we now with COVID-19? Int J Clin Pract 2020 Mar 11:e13497. doi: 10.1111/ ijcp.13497.

11. Patel AB, Verma A. COVID-19 and angiotensin-converting enzyme inhibitors and angiotensin receptor blockers: what is the evidence? JAMA Published online March 24, 2020. doi:10.1001/jama.2020.4812.

12. Stein RA. The 2019 coronavirus: learning curves, lessons, and the weakest link. Int J Clin Pract 2020 Apr;74(4):e13488. doi: 10.1111/ijcp.13488. 